\title{
HISTORY OF WASHINGTON COUNTY.
}

BY IRVING A. KECK.

We shall attempt to give the readers of the ANNaLs a brief history of the early settlement and subsequent progress of Washington County. That it contains imperfections, we do not doubt, but we have endeavored to arrive at the facts in each and every case as nearly as possible. In many instances we have had to rely entirely upon the memory of those immediately interested, and they having but little occasion to recall incidents so long past, have in many instances forgotten everything but the main facts. I am in possession of a manuscript history of the county, written by Mr. Bolens, and upon which he had spent a great deal of labor, and from which I have obtained many facts and incidents. I am also indebted to many old settlers for kindly furnishing me with many incidents and anecdotes that I could not have otherwise obtained.

At a time when the State of Iowa formed a portion of the Territory of Wisconsin, Washington County was organized, by an act of the Wisconsin legislature, into a county under the name of Slaughter, in honor of the then Secretary of the territory. This was in 1837; but during the first year but little immigration came to the county. The only inhabitants, só far as we can learn, were the Gobles, and perhaps two or three other families on Long Creek, in the eastern part of the county; Wm. and Amos Moore, in Marion township, on Crooked Creek; and Lauman Harvey, on widow Stewart's farm, one mile south-west of Washington, with perhaps a few others in the vicinity of Brighton, constituted the white population of what is now Washington County.

In 1838 , however, the county began to settle up, and records of the transactions of its inhabitants are first made. In this year a town was laid out in Oregon township, near and south of Ainsworth, by some said to be on the farm now known as the McEllherron farm, as the county seat of the new county, and called Astoria. No plat of this town appears on record, and but little of its history can be learned. We 
learn of but one building being erected in the place, and that was a $\log$ house, about sixteen feet square, for a Court House, but it was never completed as such, and no court was ever held in it. Thus passed away the first town and seat of justice in Washington County.

On Monday, the 7th day of May, 1838, the first District Court was held in and for the county of Slaughter, by David Irvine, Judge of the Second Judicial District of Wisconsin Territory. The court record says it was held at Astoria, but we learn from other sources that it was held on the farm of David Goble, in Oregon township, under a large oak tree. The grand jury held its sessions in one of the adjacent slonghs. As we are not positive of the location of the county seat at this time, this may have been at Astoria. Thomas Baker was appointed Clerk of the Court, who gave bonds for $\$ 2000$, with Nelson Ball and David Goble as sureties, and taking the required oath, entered upon his duties. The United States Marshal is not named in the record, although he seems to have been present and summoned the jury. A temporary seal was ordered, an impression of which is on record, and was taken from an old style ten cent piece. No indictments were found, no trial had, and the court, after ordering allowance for one day's services to the officers and jury, adjourned until next term.

On the $22 d$ day of October, 1838 , the second term of court was held, under a proclamation of the Governor, by Joseph 'Williams, Judge, who appointed Thomas Baker Clerk. G. A. Hen'dray, Deputy Marshal, was present; and the record says, no persons appearing either as parties, attorneys or jurors, the court was adjourned to the next term.

There had been two petitions circulated for names and presented to the members of the legislature, praying that the name of Slaughter County be changed to that of Washington. On the 25th of January, 1839, the legislature of Iowa Territory assembled in Burlington, and passed an act establishing the county of Washington. This act also changes the name from Slaughter to Washington, and appoints John Gilliland, of Lonisa County, Thomas Ritchey, of Henry County, and 
Wm. Chambers, of Muscatine County, commissioners to locate the seat of justice; establishes the temporary seat of justice at Astoria; and, attaches all of the territory west of said county to it, for judicial purposes.

The first term of court held in the county under Iowa law, was on the 17th day of June, 1839, by Judge Williams. A temporary seal was ordered at this court, but no impression appears on record. A grand jury was impanneled, but found no bills of indictment. The first case on record was for trespass. Three hundred dollars, damages were claimed by Joseph Field and Dennis Marks, surviving partners of the firm of Stone, Field \& Marks, against Milo Holcómb, which was settled at defendant's costs. J. B. and G. W. Teas were plaintiffs' attorneys, and Isaac Van Allen for defendant. G. W. Teas is known to more recent settlers as a Methodist minister, and he now lies buried at Washington, having died in 1863 . The first divorce case was begun in 1839 ; John D. Wood and his wife Elizabeth being the parties, and at the next term John was divorced. Senator Grimés was one of his attorneys. The first criminal case was tried in 1840. Lester Wallace was indicted by the grand jury of Muscatine County for passing fictitious bills, who obtained a change of venue to this county. He was found guilty and sentenced to three years imprisonment in the penitentiary at Fort Madison. The county officers at this time were, Joseph Neil and Joseph B. Davis, County Commissioners; Thomas Baker, Clerk of the Board of County Commissioners; Nathan Baker, Judge of Probate; John B. Houstun, Treasurer and Collector; Almon Moore, Recorder; John Crill, Coroner; Milo Holcomb, Sheriff.

Of these officers, the most important were the Commissioners, who, being the financial and business agents of the county, were held accountable for its good or bad management. They held their first meeting at the house of Richard Moore, about four and a half miles south-east of Washington, on Monday, 5th day of May, 1839. The first order on record is the adoption of a seal, no impression of which is, however, 
on record. At this session the county was divided into the following precincts:

1st. East Fork, township 74 and 75 , range 6. Elections to be held at the house of John W. Neil.

2d. Crooked Creek, township 74, range 7. Elections to be held at the house of Milo Holcomb.

3d. Skunk River, all of the country south of Skunk River. Elections to be held at the house of Orson O. Kinsman.

4th. Walnut Creek, the country included between Skunk River and the center of the prairie, between said river and the west fork of Crooked Creek. Elections to be held at the honse of Robt.'Risk.

5th. Washington, the country included between the center of the prairie between Skunk River and the west fork of Crooked Creek, and the center of the prairie between the west fork of said creek and English River. Elections to be held at Washington.

6th. English River, the country between the western boundary of said county and the center of the prairie between the waters of English and Iowa rivers, and the waters of Crooked Creek. Elections to be held at the house of Simon P'Teeple.

Thus it seems that the county fathers made no provision for elections for a greater portion of Jackson township and all of Highland, for the probable reason that there were no residents, and according to popular opinion at that time never would be on these large prairies. Nearly all of the settlers were to be found near the timber, and it is only within a few years that they have begun to settle at any great distance from the timber, which is always found skirting the streams.

The first grand jury which appears on record, was selected by the Board of County Commissioners, whose duty it then was, and was as follows: Wm. B. Thompson, Thos. Wilson, Wm. Ayers, David Goble, sr., Wm. Basey, John Lyon, Matthew Morehead, Richard Moore, John W. Neil, Jesse Hiatt, Thos. Ritchey, Abraham Húlock, John Hulock, Wm. L. Harvey, Nelson' Ball, Nathan'Griffith, Geo.'Parks, John Stout, 
John Grimsley, Harrison 'Goble, John Maulsbey, Daniel Powers, David Goble, jr., Wm. M, 'Fancher.

Of this number Matthew Morehead and Wm. L. Harvey are the only ones who are still residents of the county, the others having either removed to other parts of the world or have been removed by death. Mr. Morehead lives in the extreme south-east corner of the county; Mr. Harvey about eight miles south-west of Washington. The second session of the Board of County Commissioners was held at the house of Nathan Baker, now owned by the estate of James 'Law, on the 13th day of June, 1839. At this session it was ordered that the seat of justice of Washington County, which was located on the south-west quarter of section 17, township 75 north, range 7 west, by Thomas 'Ritchey and John' Gilliland, who were duly appointed commissioners for that purpose by the legislative assembly of the territory, be known and designated by the name of Washington. This and the preceding session were special sessions of the Board of County Commissioners. It will be observed that notwithstanding the county was organized in 1837 , it was not until two years after that its organization was complete, so that we may safely say that the civil government of Washington County was in perfect order and permanently established in the summer of 1839 .

The first regular session of the board was held at Washington on the 1st day of July, 1839. At this meeting, the clerk of the board was ordered to advertise a sale of lots in the town of Washington. Joseph "Crill was allowed twentyfour dollars for assessing the poll tax and taxable property of the county for the year,-a very moderate salary for a county officer.

On the 7th of September, 1839, an order for erecting a temporary Court House was made, and on the 21st of October Milo Holcomb, sheriff, offered the same at public outcry, and it was struck off for seven hundred and fifty-nine dollars to Joseph 'Neil. On the 23d of November, a written contract was entered into for the erection of this building on the lot now owned by A. W. Chilcote, and occupied by Chilcote \& Brothers on the south-west corner of the square. On the 8th 
of July, 1841, this house was received by the county from the contractor upon deducting one hundred dollars from the contract price, because the work was not done in a workmanlike manner. The building is now used by M. C. Kilgore as a stable on his premises, in the north-east part of town.

April 7, 1841, Wm. Pickérel was licensed for two dollars a year to keep a ferry across Skunk River, above his mill, which then stood where the Brighton mills now stand. The rates of toll were $6 \frac{1}{4}$ cents for each footman; horse and man, $12 \frac{1}{2}$ cents; single horse and wagon, 25 cents; two horses and wagon, $37 \frac{1}{2}$ cents ; for cattle, sheep and hogs, $6 \frac{1}{4}$ cents per head, driver in all cases included. This was the first ferry established in the county; this ferry was licensed to Thos. J. Gor- $v$ don July, 1843. On 3d of July, 1848, Thompson 'Dray received license for five years for two dollars for the first year and such amount as may be determined by the board for the remainder. The same day the clerk of the board was required to give notice by written advertisement, in three of the most public places in the county, that the building of a wooden jail will be let out by private contract on the 1st day of June next. Alex. Lee, J. B. Davis and Thomas Baker' secured the contract, and were ordered to build the jail on lot three, block eight.

On the 13th day of August, 1842, the following appears on record:

Received of the Board of County Commissioners the sum of $\$ 1020$, as follows: $\$ 984$ in county orders on the town of Washington, and lot five, block two, lot six, block eleven, for thirty-six dollars, all being in full payment of my several contracts to build, finish and complete a county jail in said town of Washington. Witness, \&c.

Alexander Lee.

By which it appears the other two contractors were relieved in some manner, and Mr. Lee assumed the whole contract. This building stood upon the lot just back of N. Everson's large brick building, and was used as a jail until it became a perfect disgrace to the county, when Norman Everson purchased it from the county and demolished it. Since then the 11 
county has been without any such receptacle for its criminals, but sends them to Muscatine to be boarded.

On 5th of October, 1841, the Board ordered that the Clerk contract with Albert Sturgess, for seventy dollars, for the enclosure of the public square by the first of April next. The contract was made, and subsequently extended to the first Monday in July, 1842, but for some reason, the enclosure was never made under the contract.

January 3,1844 , the county was, for the first time, divided into the following townships: Iowa, English River, Lime Creek, Crawford, Marion, Washington, Cedar, Brighton, Dutch Creek and Clay. On the first Monday of April, 1845, English River, Lime Creek, Dutch Creek, Brighton and Cedar townships were organized into townships. Wm. R. 'Harrison was employed for one year from January 7, 1845, as attorney and counselor for the Board, at a salary of twentyfive dollars per year.

February 18th, 1845, a contract was entered into with Alexander Lee for the building and completion of a Court House in the town of Washington. On the 7th of July, 1847, Mr. Lee presented the Court House for acceptance, but the Board rejected it, and, upon agreement, the matter was referred to Henry Guseman, Lyman 'Whitcomb, David P. 'Sturgess, B. P. 'Baldwin and P. C.'McKinney, who deducted, on account of carpenter work on the cupola, $\$ 50$, on the balance of the building, $\$ 110$, which was accepted by the parties. This is the building now used by the county as a Court House, and with whose homely phiz every citizen of the county is familiar.

On the 13th of April, 1847, Mr. Lee, the architect of this magnificent structure, was allowed to have any of the unsold lots in Washington at five dollars each, on his Court House contract. This price seems now to have been very low indeed, but it must have been considered high at that time, as $\mathrm{Mr}$. Lee does not appear to have taken much advantage of the liberal offer of the Board.

The last session of the Board was held on the 28th day of July, 1851, at which time the only business transacted was 
the levy of taxes for that year. The Board, at this meeting, was composed of Michael 'Hayes and John B.'Webster, the third Commissioner, Mr. $\cdot$ Robinson, being absent.

\section{POLITICAL.}

In the earlier days of county existence, politics did not trouble its inhabitants to any very great extent; one reason of which probably was the pay being so small. The collector of taxes for the years 1840,1841 and 1842 received but $\$ 151.60$ for his services; and as late as 1843 and 1844 , the treasurer's annual salary did not amount to more than $\$ 100$. Until 1846, politics did not turn upon party, but on the best man for the place; the result of which has been a faithful set of officers, as a class. There was some difficulty with the first treasurer, Liston A.'Houston, who died indebted to the county some $\$ 1500$. On the 8 th of October, 1845 , on Jonathan H. Wilson coming into office as County Treasurer, he made his report to the Board of County Commissioners, and was ordered to collect the balance due from Mr. Houston; also giving Mr. Houston's securities until the first Monday in January, 1846, and no longer, to make full payment. The time was, however, extended to April. Also with S. M. Cox,' treasurer from 1856 to 1860 , there was some difficulty in making his affairs appear all satisfactory.

Up to 1846 , at times both candidates belonged to one party. Since that time, however, party lines began to be more closely drawn, and the county has generally been anti-democratic; now and then a democrat gaining office on some local issue, but the general result has been whig, know-nothing, republican or radical, as to county politics. The most exciting contest was in 1857 , which was in relation to the County Judgeship, several questions entering inte the contest, among which was the issuing of bonds by the county to the M. \& M.' R. R. Co. The election was very close, there being three candidates, Samuel P. 'Young, Joseph 'Dickey, and Enoch Ross, each receiving votes as follows: Young, 707; Dickey, 710 ; Ross, 335. The canvassers, however, rejected the returns of Cedar township, on account of some informality in 
the returns, which left the vote stand, Young, 688 ; Dickey, 668 ; and Ross, 303. The matter was contested on behalf of Mr. Dickey by Thomas Blanchard. The parties selected to determine the matter were Joseph R. Lewis, M. Duke'Story and James'Dawson, who, after hearing the case, decided that Young was elected; not, however, on the same count as before made by the canvassers, Cedar township being counted and Jackson township being thrown out on account of some defect in the returns. The vote then stood, Young, 694; Dickey, 692; Ross, 287. The person declared elected had concluded not to accept the office, but subsequently changed his mind and qualified. Since that time nothing has trans. pired of any very great importance in county politics.

NEWSPAPERS.

The first newspaper published in the county was the Washington Argus, established in 1854, by Lewis F.' Walden, and edited by J. F. 'Rice, and after being in a half-starved condition for one or two years, it went up Salt River; the last heard of it was in a note by one of the proprietors, stating that those to whom papers were due could be supplied with copies of the Press for the proper amount in each case.

I am in possession of the only copy that I know to be in existence, which bears date June 8,1854 , flaunting at its editorial head the Democratic State Ticket. It is a six column paper, well printed, and was edited with vim, judging by the way in which it pitches into James W. Grimes, in an editorial of over a column in length. There is no marriage notice, but the obituary of Margaret, consort of Andrew Spillard, who died of palpitation of the heart, aged fifty years. Among the advertisements we find that of J. C.'Howe, who announces an important discovery to the citizens of Washington County, which is, that he will supply them with wagons; the law cards of A. H. "Patterson, Norman Everson, J. B. McNay; the medical cards of W. H. 'Roussean, E. R. 'Young, J. B. Combs; dry goods, Marsh \& Holden, N.'Chipman, George 'Thompson, Dougherty \& Pollock, 'Cleaves \& McElroy. Grocery by J. McClelland \& Son; stoves, \&c., by Shaw \& Cor- 
bin, and some others. The subscription price was two dollars per year, and three dollars for announcing candidates for office. Advertising rates were about the same as now. The 'Washigton Press was established by A. R. 'Wickersham, in 1856, the first number bearing date of April 9, 1856. Among the advertisements in this number is found a notice of the annual meeting of the Kansas League of Iowa, signed Chas. Foster, chairman of Executive Committee. Summer term of Washington College, list of letters, Mrs. Mary Parker, P. M., Dr. M. C.'Parker, Homœpathic and Hydropathic physician, G. W. Thompson \& Son, 'Corbin \& Ferguson, N. 'Chipman, Marsh \& Holden, A. W.'Chileote, W. H.'Jenkins, and a few other cards.

The Press is now the oldest paper in the county, having been owned in whole or part by A. R. Wickersham, A. S. Bailey, now one of the proprietors of the Record, Thaddeus $\mathrm{H}$. Stanton, now a paymaster in the regular army, and is now owned and edited by H. A. 'Burrell.

The Washington Democrat was established in 1860, by E. B. Bolens, its first number being dated November 22d; Mr. Bolens being both editor and proprietor from its inception to the close of its career. He was compelled, twice, to suspend its publication for a few months, on account of inadequate support, before he finally abandoned it entirely in 1866 . Mr. Bolens removed to Janesville, Wis., where he now is editing and publishing the Janesville Democrat.

In June, 1857 , the students of Washington College published a paper called the Bower of Literature, but the investment not proving profitable the Bower soon died a natural death. In June, 1867, the Record was started by Messrs. A. S. \& S. P.'Bailey, and is edited and published by these gentlemen. In July, 1868, the Pioneer was first issued at Brighton, R. H.'Moore editor and proprietor, and since we began writing this article, we notice the prospectus of the Vindicator, the initial number of which is to be issued in a few days. It is to be democratic in its teachings. This ends the list of newspapers published in the county, with three radical and one democratic. We surely should be able to find out what 
is for our best interests. The Pioneer, Record and Vindicator being of more recent date, we do not give an extended notice of them.

CRIMTF.

Washington County like almost every county has its criminal record, but has been comparatively free from murders until the last year, when we had two within a few days of each other, one being Thomas 'King, by Mc'Nally, who has not been tried, an indictment being found only last term of the District Court; the other, Dr. J. T. 'Sales, one of the old residents of the county, was shot on the streets of Brighton by one Hogue, who made good his escape. These we pass with this brief notice, and take those of an earlier date, in the order in which they occurred.

The first occurred in what is now Mahaska County, but that county being then attached to this for judicial purposes, we give its history here. On the 31st day of May, 1841, in Clay township, Peter 'Perry was murdered by Elijah' Searcy. Searcy was indicted by the grand jury in November following. On the $2 \mathrm{~d}$ of June, 1841, J.M.'Smith, justice of the peace, issued a warrant for the arrest of Searcy, which was executed by John Pennington, constable, on the 4th of June; on the 9th of June an inquest was held on the body of Perry before Orson O. Kinsman, justice of the peace; the jury returned a verdict that said Perry came to his death from a wound received from a club in the hands of Searcy on the 7th of June. Searcy sued out a habeas corpus before Judge Jos.' Williams, by Olney and Negus, his attorneys, but nothing appears to have been done. On the 9 th of June, a recognizance was taken by J. W. 'Houston for Searcy's appearance, the bond being fixed at $\$ 1000$, by which it appears he was released from custody. On the 25th of November, 1841, an indictment having been found, a warrant was issued for Searcy's arrest, and a pluries on the 5th of May, 1843, both of which were returned without service. The criminal having disappeared this case was never tried.

The circumstances of this case were about as follows: It appears that Perry was a half-witted sort of a fellow and was 
made the butt of a great many practical jokes. He having said something disparaging to the reputition of Searcy's sister, a quarrel ensued which resulted in the killing of Perry.

The next murder was that of William ' Johnson by John 'Peck, in Mahaska County, on the 9th of September, 1843. The circumstances of this murder were as follows: Johnson, who claimed to be one of the heroes of the Canadian revolt, came to the county bringing a very prepossessing woman whom he passed off as his daughter, and to whom Peck was subsequently married. A quarrel arising between the two men about the marriage, Johnson went to Peck's house and took his wife off. Peck with gun in hand went to George vlarkson's house where Johnson was, and without going in deliberately shot Johnson through the cracks of the logs, the shot taking effect in the right breast, killing Johnson immediately. At the October term, 1843, of the District Court, Peck was indicted for this murder, and was tried at a special term held in November, 1843, Joseph ${ }^{\gamma}$ Williams, judge, at which time Peck was acquitted.

The third indictment was that of William 'McCauley for the murder of Don Ferdinand 'Coffman, in English River township, on the 4th of Angust, 1844. A change of venue was taken to 'Van Buren County, where he was tried, convicted and hung. The circumstances of this case were about as follows: MeCauley claims that an intimacy had grown up between himself and the wife of Coffman, which terminated in a quarrel between the men. Many threats were made one against the other until the day of the tragedy, when Coffman on a horse with a child before him rode through a lane, and McCauley was coming through a field with a gun. When he reached the fence at a point about eighteen feet from the rictim of his hate, he fired, the ball passing through the body of the child, killing it instantly, and entering the body of Coffman, causing a wound, from the effects of which he died next day. He also claims that Coffman's wife and others persuaded him to commit the deed. The evidence shows that McCauley before, at the time of, and subsequent to his arrest, admitted the murder, claiming that he did not intend to kill the child. 
The next case was that of John C. Herriman, who was indicted for the murder of David H.'Miller on the 9th day of August, 1848, on the farm of A. J.'Disney, in Marion township. This was the most cool and deliberate affair of the kind that ever occurred in the county. The indictment was found on the 5th of September, 1848. At the September term, 1848, Harriman was arraigned and pleaded not guilty. No trial was had owing to the case being continued. At this term the defendant nioved that some indifferent person be appointed elisor to summon jury and act as sheriff during the trial, as he verily believes Jonathan H. ${ }^{v}$ Wilson, the sheriff of said county, is prejudiced against him. Accordingly, at a special term held the 30 th of October, 1848 , Robert Kinkade was appointed such elisor for that term. The jury were then sworn, who, after hearing the evidence, returned the following verdict: On the $2 d$ of November, 1848, we, the undersigned jurors, find the defendant guilty of the charge of murder as stands charged in the indictment. The judge then passed the following sentence:

The sentence of this court then is, that you be remanded back to the jail of this county and remain there until Friday the 17th inst., that on that day you be taken thence to the place prepared for execution, and there, between the hours of one and three o'clock of said day, you be hung by the neck until you are dead, and may God have mercy on your soul.

Previous to this sentence being passed Herriman moved an arrest of judgment, which was overruled, and the case was taken to the Supreme Court on a bill of exceptions, assigning twelve errors. The Supreme Court reversed the decision of the District Court, and ordered a new trial, which was held upon a change of venue at Fairfield, where a verdict of manslaughter was returned, and Herriman sentenced to eight years confinement in the penitentiary at Fort Madison. About three years afterwards Gov. Hempstead pardoned him, and he was released. The last that we know of Herriman, he had gone across the plains, where if he has not improved very materially he has probably met ere this his just doom at the hands of some vigilance committee, without 
80 much of law to prevent his sentence being carried into effect.

The circumstances of this case were about as follows: Previous to the election it was rumored that Herriman was a convict, having served a term in the Ohio prison, and consequently not entitled to a vote, and several had threatened to challenge his vote, which, however, was not done. These rumors having reached the ear of Herriman, who being dissipated and quarrelsome, said he would "show any man" who should do so. Several days after the election, Herriman went to the residence of Mr. Disney, where were also Messrs. Moray and ${ }^{1}$ Sewell. Herriman being intoxicated, it was with much difficulty that a quarrel was prevented. After some considerable talk, Herriman became somewhat quieted, and the party went to the fence in front of the house. About this time Miller, the murdered man, rode up on a horse, having a child with him. Miller stopped, and Herriman said, "And you are another of the $\mathrm{G}-\mathrm{d} d-\mathrm{d}$ sons of $\mathrm{b}-\mathrm{B}$ who was going to challenge my vote." Miller, setting the child off the horse, got off himself, saying, "Well, what are you going to do about it?" Herriman replied, "I'll show you," and at the same time fired, killing Miller almost instantly. The others of the party, Messrs. Disney, Moray and Sewell, immediately surrounded Herriman and attempted to arrest him; but he showed fight, using his gun as a club, he kept them at bay. Herriman, retreating backwards, stumbled over a $\log$, when Mr. Disney, eatching his gun as he fell, wrenched it from his grasp and dealt him a blow over the head as he lay upon the ground, which, if the butt of the gun had not struck the ground before it did Herriman's head, would have precluded the need of either judge or jury.

At the time Herriman was sentenced to be hung, the gallows were all prepared on the ground east of and adjoining the cemetery, in the south-west part of town, and a large crowd gathered in town; but their curiosity was not satisfied, as a messenger, bearing a stay of proceedings from Judge 'McKinley, of' the Supreme Court, arrived about three hours 12 
before the time for the execution. Mush disappointment was manifested, but no disturbance took place.

The next murder, and the last until the present year (1868), was that of Jonathan Dewees, on the 15th of July, 1859 , in Marion township. The circumstances are substantially as follows: Near Van Doren's old mill stood a small house which was used as a bawdy house, which had become very annoying to the neighbors, so much so that they concluded to take the law in their own hands and abate it as a nuisance. On the evening of the day named, about a dozen men proceeded to the honse to carry their determination into effect. Meeting with resistance, a fight ensued. The assailants were fired upon, one shot taking effect upon Mr. Dewees, the ball entering the back between the shoulders and passing through the chest. He lived but a few moments afterward. There were two men and two women in the honse at the time, but it is presumed that Arnold'Custer, one of the men, fired the fatal shot. In the excitement he made good his escape. He was indicted for the murder by the grand jury, but has never been and probably never will be arrested, and the indictment still stands against him. The last known of him he was in California. From that time until the present year we have been exempt from such evils.

In every case, excepting the murder of Dr. ${ }^{\prime}$ Sales, the cause can be traced directly either to bad whisky or bad women. Of minor offenses we have had the usual share, but matters seem improving of late years, and there are comparatively few arrests, and the greater part of those for small crimes.

(To be Continued.)

\section{FRANKLIN WELLS.}

We publish in this number the portrait of the late D. Franklin Wells, Superintendent of Public Instruction of the State of Iowa, at the time of his death; and below the funeral services and sermons which formed a part.

Throughout the State, wherever his name is known, and his influence has been felt, and his services are appreciated,-and there is no place within it where they are not,-it will, we are satisfied, be perused with interest. 
Copyright of Annals of Iowa is the property of State of Iowa, by \& through the State Historical Society of Iowa and its content may not be copied or emailed to multiple sites or posted to a listserv without the copyright holder's express written permission. However, users may print, download, or email articles for individual use. 